\title{
Divergent Accounts of Equivalent Narratives: Russian-Swedish Interdevochka Meets Swedish-Russian Lilya 4-ever
}

\author{
Lars Kristensen, University of St Andrews
}

When Margareta Winberg, then Deputy Prime Minister and Minister for Gender Equality in Sweden, took up the film Lilya 4-ever (2002) for public debate in 2003, she made it clear that the film's most important function in her view was its depiction of gender equality. As a consequence of this admiration from the political establishment, the Swedish Foreign Ministry was assigned to 'export' the film to countries from where human trafficking originates: Russia and Eastern Europe. The aim of this 'export' was to reach political decision-makers - and opinion-makers — and to make explicit what facts and statistics had failed to do, that is, make the horrors of human trafficking tangible (Hedling 2004, 327). This seemingly transnational ${ }^{1}$ feminist concern has larger consequences beyond the intentions of the film, because it makes explicit the postSocialist power system that emerged after the fall of the Soviet Union. Here Sweden and the West as a whole hold the banner of educators, and the post-Socialist countries are the uncivilised learners, a phenomenon already described elsewhere (Wolff 1994; Neumann 1996, 1999).

By demonstrating how Lilya 4-ever performs a Russian 'return' narrative, in this article I want to underline the ways in which the story of Lilya adheres to a European 'anxiety'

\footnotetext{
${ }^{1}$ In this essay, the transnational has different connotations than the international. Where the international is considered as a bilateral, or multilateral, connection between states, the transnational is interconnected at the level of people, e.g. work co-operation. In the words of the Swedish anthropologist Ulf Hannerz, the transnational is a 'more humble, and often a more adequate label for phenomena which can be of quite variable scale and distribution' (quoted in Bergfelder 2005, 321).
} 
narrative. The transnational mobility made possible since the lifting of travel restrictions in the post-Socialist countries informs this anxiety, which envisions hordes of migrant workers flooding the nations in the West and undermining their respective welfare systems. Contrary to Moodysson’s intentions-as he states in a Swedish tabloid newspaper interview, 'if the film could make one young girl reconsider, then I have succeeded' (Hjerten 2002, 36) ${ }^{2}$-his film reiterates a prevalent European narrative of the transnational post-Soviet Russian girl/woman. My major concern with Lilya 4-ever is not its horrific portrayal of human trafficking, which the film depicts with genuine credibility, but with its end flight into a 'return narrative' for its female protagonist, a salient Russian, and in particular Soviet, convention in cinematic representations of Russians abroad.

Rather than arguing that Lilya 4-ever is a misrepresentation or wrongly structured, my intention is to lay bare the transnational context as significant for the understanding of representations of post-Soviet female Russians in north-western Europe. I want to compare Lilya 4-ever to a late Soviet glasnost film, Interdevochka [Intergirl] (1989), directed by Petr Todorovsky, which tells a similar story of a female Russian travelling to Sweden. We have, then, two cinematic accounts of female Russians travelling to Sweden; both have opted for selling sex acts and both move to Sweden with the intent not to do it again. However, there is a big age disparity between the two Russian females, for Tanya in Todorovsky’s film is a woman and Moodysson's Lilya a child. This has consequences for the comparison of the films, as the narrative paradigm shifts depending on the maturity of the protagonist. If, for Tanya the empowered sex worker, hers is an informed transnational journey, Lilya's is a child's grim journey of human trafficking. Yet, despite their differences, a comparison of the films enables a critical shift from the national level to the transnational. For example Lilya 4-ever has been dealt with as a Swedish film (Hedling 2004) and a contemporary European child narrative (Wilson 2005), while Interdevochka has been analysed as a Russian melodrama (Lawton 1992, 211-13, and 2004, 61; Gillespie 2003, 98). These traditional film/language studies accounts are useful, but they are all set in homogeneous contexts that exclude each other. By fusing the Swedish/European and the Russian/post-Soviet

\footnotetext{
${ }^{2}$ The interview appears under the headline: 'The film is pitch-black—-[Moodysson] wants the audience to change their lives—and resonate’ (Hjerten 2002).
} 
contexts, my analysis aims at going beyond national particularities and providing a fuller transnational account of Post-Soviet Russian females travelling abroad.

\section{Transnationalism, Nordic Identity Formation and Post-Socialist Migrant Workers}

In contemporary film studies, the transnational has come to inform understandings of cross-border cooperation, emigrating star personas, and cross-cultural audience readings, whether the topic of analysis is Hollywood, national or global cinema. The transnational focus emphasises movement beyond the national, and makes unstable 'the ability of cultural authorities to deploy the binarized us/them narratives upon which xenophobic nationalism depend' (Ezra and Rowden 2006, 4). In this way, the concept of the transnational has replaced the once progressive postcolonial, which, as Ella Shohat writes, 'has given way to a politically drained post-colonial term, due to the collapse of the Second World and the crisis of socialism' $(1992,101)$. The transnational, in this sense, refuses to take sides with either the top (champions of capitalism) or the bottom (various forms of Marxism and socialism), but rather 'unfolds as an essentially selfmotivated, and apparently amoral, cultural force’ (Ezra and Rowden 2006, 9).

Transnational cinema in this sense owes much to the older postcolonial cinema or Third World cinema, only here, as an 'amoral, cultural force' it can make a claim to being devoid of ideological connotations. While it is easy to be hyperbolic and discuss the transnational as a new form of enriching cosmopolitanism, I believe it is useful to insist on a conception of transnationalism that still contains an us/them, a top/bottom, and a First/Third World. This is because transnational female post-Soviet Russians ${ }^{3}$ represent the loss of the Second World, and thus signify the uneasiness with which they are positioned within the First/Third World dichotomy. Therefore, I will discuss here the context of Lilya 4-ever as (re-)establishing a Swedish self where the female Russian is not part of First World Sweden, but represents that world's Other. In short, although Lilya 4-ever depicts a transnational movement, the film (re-)produces the (neo-)colonial discourse of 'us' and 'them.'

Nordic cinema, which includes several minor national cinemas, is traditionally

\footnotetext{
${ }^{3}$ In particular, Russian women seem to fascinate (male) filmmakers, as can be seen in a trope of British films, from the glitzy starred Birthday Girl (2001) by Jez Butterworth, with Nicole Kidman in the leading role, to the realistic Last Resort (2000) by Pawel Pawlikowski, which stars Dina Korzun as a vulnerable and naïve young Russian mother.
} 
considered transnational in its objective to fend off the cultural influx from the USA and Hollywood. Mette Hjort analyses Nordic co-productions as shifting towards a homophilic transnationalism, where 'the assumption, expressed by filmmakers, producers, and policy makers from the mid-90s onward, is that co-operation across national borders is far easier in the Nordic context' (2005, 210-1). The rationale here is that the Nordic countries share cultural, linguistic and historical affinities, an idea that translates as 'we co-operate (communicate) with those similar to us.' This form of transnational cooperation has its limitations, of course, in that it does not include crossborder communication with those dissimilar to 'us.' Russians would be a case in point. Lilya 4-ever was a Nordic co-production between Swedish Memfis Film and Danish Zentropa, and there is no evidence of Russian involvement in the film's production. Newspaper reports on the film state that Moodysson and representatives of Memfis Film went to Moscow to organize casting auditions. ${ }^{4}$ Thus although the film is a transnational production, and was made in line with the homophilic transnational cooperation identified by Hjort, no Russians participated in the production. Indeed, the Nordic transnational co-production of Lilya 4-ever was sought in order to enhance the possibility of applying for grants within both the Swedish and the Danish funding agencies and allocating audiences beyond the national borders. ${ }^{5}$ Frequently, European co-productions seek transnational partners when venturing outside the national context in order to gain local experience, audiences and funding, and to make filming cheaper, given that transporting a film crew and equipment to the desired transnational location is an expensive exercise. ${ }^{6}$ The transnational in Lilya 4-ever's production scheme points to a different kind of Nordic identity formation, a kind that does not need the incorporation of the post-Soviet Russian. The film's intention, I argue, is to portray cultural concerns that largely address the Nordic context. ${ }^{7}$

\footnotetext{
${ }^{4}$ Alexandra Dahlström, who starred in Moodysson's first film Show Me Love (1998) as Elin, worked during the shooting of Lilya 4-ever as a Russian interpreter. Dahlström’s mother is Russian.

${ }^{5}$ The two film companies have a long-standing working relationship and are similar in their position outside the established national film industries.

${ }^{6}$ It should be noted that Memfis Film co-operated with Russian STV Film Company in the production of another film from 2002, Bear's Kiss by Sergei Bodrov Sr. This link with STV is further emphasised by the leading actress in Lilya 4-ever, Oksana Akinshina; she starred in Sergei Bodrov Jr's acclaimed debut film, Syostry [Sisters] (2000), which was also produced by STV Film Company. Despite this formal affiliation with STV in St Petersburg, Memfis Film took on the job of producing Lilya 4-ever without cooperation from their Russian partners.

${ }^{7}$ It should be noted that Interdevochka was also a transnational collaboration with Soviet Mosfilm and Swedish Filmstallet. However, in the case of Interdevochka, the coproduction was sought to ease the shooting of the film. Unlike Lilya 4-ever, there is no evidence that Interdevochka had a transnational viewer strategy and the film was not released in Sweden.
} 
The Norwegian political scientist Iver Neumann has examined Russia’s role in the identity formation of the Nordic region, as part of the larger European identity formation (see also Wolff 1994). According to Neumann, the construction of the region partly hinges on two approaches, the inside-out model and the outside-in model (1999, 117-122). The inside-out model sees the region as sharing affinities, which render transnational cooperation as natural and proper. This is the model on which Hjort's homophilic transnational cinema seems to operate, as noted above. The other model, outside-in, establishes itself on a geopolitical level, where the geographical region's position in between powerful states_-Great Britain, Germany and Russia—constructs a forced affinity of the region as a counterweight to these states. Here, the identity formation works in reverse order to that of the inside-out model, where those 'who we are not' inform the consolidation of 'who we are.' I read Lilya 4-ever in this context, that is, as a (European) Nordic narrative in which the Russian female is constructed as the non-European Other. This post-Socialist female Other fascinates us because we find her social decline unjust and horrific. The post-Socialist decay portrayed in Lilya 4ever - the grey housing blocks, the courtyard's muddy look, the derelict marine baseall register as despair on the faces of the characters, which in turn rouses the viewers' empathy and desire to rescue the film's victims.

Moodysson's rescue attempt lies outside the film's narrative of Lilya, who is grossly abused by people uninterested in helping her. Moodysson wants to 'save' the postSoviet girls, who desire to travel to the West, by making explicit the mechanism of human trafficking and the Western male sexual desire for prostitutes that facilitates such trafficking. In this regard, the film constructs the post-Soviet Russian female girl as Other and as victim. As the Swedish film scholar Olof Hedling has asserted, 'the characters are reduced to victim/slave and perpetrator/slaver' (Hedling 2004, 324). ${ }^{8}$

Leaving aside the fiction of Lilya 4-ever for a moment, I want to highlight how postSocialist labour migration functions outside its cinematic representation and, in particular, how women play an important role in this system of transnational movement. Leyla Keough undertook research in the Gagauz region in Moldova, where she

\footnotetext{
${ }^{8}$ Hedling (2004) argues that Lilya 4-ever has similarities to early 20th century representations of immigrants, as seen in the US film Traffic in Souls (Tuckers 1913) or the Danish film Den hvide Slavehandel [The White-Slave Trade] (Alfred Lind 1910).
} 
conducted interviews with women who travel regularly to Turkey in search of work. She says,

[t]he blame for social disorder in Moldova is placed upon migrant women-especially those who work in Turkey, who are represented as irresponsible mothers, immoral wives, and selfish consumers. Migrant women themselves counter that local disorder and their migrant work is caused by economic dislocation. They argue that in going abroad to work, they are selflessly sacrificing [themselves] for their children and thus are those more resourceful and better mothers (even if transnational ones) than those who stay. (Keough 2006, 432-33)

The women that Keough talked to were narrating a different story, where the 'good mothers' leave for work in neighbouring countries in order to better their domestic situation. Given that Moldova is not part of the post-Soviet Baltic, which is the context for Lilya 4-ever, Keogh's findings do shed light on a new transnational migration circuit in post-Socialist countries (441). Here the neoliberal economics imposed by First World institutions, such as the IMF and the World Bank, have stripped the nation-state of its responsibility for providing a social welfare system and creating jobs at home, hence the economists' advice to use the 'migrant labour as a tool for development' (454). This is why the political involvement in exporting Lilya 4-ever to post-Socialist countries becomes incriminating and looks more preoccupied with anxiety about migration than with the welfare of its post-Socialist subjects.

Since I want to compare Lilya 4-ever with the Soviet Russian narrative in Interdevochka, I will, as a way of distinguishing the stories, term Lilya 4-ever a Swedish-Russian narrative and Interdevochka a Russian-Swedish narrative. Even though both films tell the story of a Russian female travelling to Sweden, their contextual, temporal and ideological frameworks are different. Lilya 4-ever may have Russian as its major language, yet it remains a Swedish film informed by Scandinavian identity concerns and world-view, as will be clear from a brief plot analysis. ${ }^{9}$

\footnotetext{
${ }^{9}$ That said, when Lilya 4-ever premiered in Britain in 2003, Julian Graffy wrote in Sight and Sound, 'it is one of the considerable strengths of Lilya 4-ever that the Swedish Moodysson has made such a convincing “Russian” film' $(2003,21)$. The inverted commas around 'Russian' imply that the film is, in fact, Russian, although Moodysson is Swedish and not Russian. And not only due to the fact that Russian is the major language in the film, but because, according to Graffy, it tells an 'authentic' Russian story. Graffy is referring to the drabness- 'the faceless, unmaintained blocks on the edge of an unnamed town, the derelict and trashed public spaces, the meagre adornments of Lilya's room' (21)—which is the postSocialist Estonian setting of the film. Graffy's inverted commas are warranted; but not in the way Graffy implies. That is, they could be seen to indicate the film's 'inauthentic' look, as it is narrated by a Swedish European who constructs the post-Socialist Russian in line with a Eurocentric view of the Other.
} 


\section{Swedish-Russian Lilya}

The mother of teenage Swedish-Russian Lilya abandons her in a post-Soviet country ${ }^{10}$ when she leaves for the USA with her new husband, a Russian-American. Lilya's situation goes from bad to worse until she has no other way out than to follow the path of a friend into prostitution. On one of her nights out, she encounters Andrei, who at first appears to be the decent person that Lilya has lacked all her life. In good faith, encouraged and aided by Andrei, Lilya travels alone to Sweden with a promise of work—picking vegetables_-and an assurance that Andrei will join her later. However, Andrei turns out to be part of a trafficking network. Once in Sweden, Lilya is stripped of her fake passport, raped, and forced into prostitution in a cold and ruthless society. Finally Lilya escapes and commits suicide by jumping off a bridge. In death, back in her post-Soviet country, she rejoins her soul mate, a boy called Volodia, who had committed suicide after Lilya’s departure to Sweden.

If not a blockbuster, Lilya 4-ever was a considerable critical success. Swedish critics, in particular, pronounced it a masterpiece. The film critic Ingvar Engvén, writing for the Swedish film industry's journal, applauded the film as a 'harmonious masterpiece' (Engvén 2002, 35). He was not alone in his appraisals (for further examples, see Hedling 2004, 326). The film was much anticipated in Britain, as confirmed by the prepremiere article by Julian Graffy in Sight and Sound (2003, 20-22). But the following issue of the journal ran a review of the film that expressed disappointment and strayed far from the plaudits of 'masterpiece.' According to the review by Tony Rayns, '[the film] says nothing more useful than: isn't this shocking? Aren't we powerless to do anything about it?,' and he continues, 'Lilya is a brattish Russian teenager, formed by her tough environment, but ultimately a tabula rasa’ $(2003,56) .{ }^{11}$ These opposing reviews indicate that critics were divided over the film and its portrayal of post-Socialist

\footnotetext{
${ }^{10}$ The country of origin in Lilya 4-ever is never determined in the narrative, but stands for a post-Soviet condition rather than one particular state. That said, the shooting location was in Estonia, the Baltic country that the Nordic countries have regarded as the prime target in the region for political and economic cooperation. The historical bond between Scandinavia and the Baltic is alleged to be the reason for this esprit de corps.

${ }^{11}$ It should be noted that not all reviewers outside Sweden were unhappy with the film. Kristin Marroitt Jones praises Moodysson for not exploiting 'Akinshina's doll-like prettiness by presenting it as anything but a magnet for predatory men’ (2003, 74). The New York Times review contradicts Tony Rayns’s view of Lilya as 'brattish' by saying that it is a heartbreaking film because Lilya is not 'an overprivileged brat mopily foraging in a land of plenty’ (Holden 2003, E20).
} 
trafficking. ${ }^{12}$ In the Nordic context, the victimization of Lilya, which Rayns finds so revolting, is accepted as a given post-Socialist reality. In this way, at the level of regional identity formation, as we saw in Neumann's assertions above, the Nordic countries foster a Russian Other against which their own national identities are projected. Moreover, the Russian Other is outside the traditional homophilic transnationalism that shares values and identities; although near in geographical terms, Russia remains remote in reality.

Moodysson leave the space of his narrative elusive and undefined in terms of geography. Therefore the film does not speak particularly of the post-Soviet Estonian context, in which it is filmed, nor about the particulars of the Swedish town of Malmö. Rather, Moodysson pinpoints social conditions that converge: post-Soviet economic poverty and north-western European economic affluence and exploitation. However, when Moodysson addresses Russian audiences, he stresses that the film speaks of a Swedish/Nordic reality, ${ }^{13}$ which, in my opinion, underlines the aim of the film. Mooddysson's targeted aim is the social critique of north-western European affluence, and to a lesser degree of the post-Soviet condition, which is offered only as a context. In January 1999, Sweden introduced a law that made it illegal to pay for sex acts, while it still remained legal to sell sexual favours. The law discourages prostitution without criminalising sexworkers: it targets the men who purchase sex, while decriminalising the women. In Lilya 4-ever, Moodysson also targets the men through the camera work. In a montage sequence during the treatment that Lilya endures from the men she is sold to, the camera assumes the position of Lilya looking up or down on the grunting men, who because of Lilya's age (16), are essentially paedophiles. ${ }^{14}$ During the interview on

\footnotetext{
${ }^{12}$ This split can also be detected in the audience numbers obtained from the Lumiere Database. Although released in 23 countries across Europe (still exceptional for a contemporary European film), only 600,000 people attended screenings of Lilya 4-ever Europe-wide. Compared to Moodysson's two previous films, this is a considerable drop, Fucking Amål [Show Me Love] (1998) was seen by 1.5 million viewers across Europe and Tillsammans [Together] (2000) by nearly 2 million. Of Lilya 4-ever's 600,000 European viewers, over 400,000 came from the Scandinavian countries alone, and 300,000 of these from Sweden. This viewing pattern, which fused with the uneven critical reception, indicates a split in the acceptance of the film's message. The different British-Swedish reception of Lilya 4-ever can also be explained by the different cinematic traditions, as Nordic cinema has a stronger and more developed tradition of childcentred dramas, which in turn reflects different attitudes to children and child-care.

${ }^{13}$ For example, when interviewed in Rotterdam for the Russian newspaper Gazeta, Moodysson says, "I think that Lilya 4-ever is not just a Russian theme. This is a global situation. Not in the details, of course, but in the aim that in many countries people are enduring difficult experiences. I did not set out to concretely make a film about Russia. Rather about Sweden - in so far as Lilya turns up in that country. And when Swedes watched the film, afterwards they spoke about a Swedish reality” (Chen 2005).

${ }^{14}$ The age of consent in Sweden is 15, but in cases where the person is either the offspring or in the care
} 
the DVD edition of the film, Moodysson explains that the cameraman became physically sick while shooting in this position and that Moodysson himself shot some of these horrific scenes. ${ }^{15}$

Moodysson aims to place the spectator in the position of the exploited, Lilya, laying bare these newly criminalised men and their sexuality. Moodysson's investigation of middle-aged, male (hetero)sexuality — a line of examination which he continues in his following two films, Et hål i mitt hjerte [A Hole in My Heart] (2004) and Container (2006) — becomes in Lilya 4-ever a quest into a male sexuality that facilitates prostitution and human trafficking. Any portrayal of human trafficking is horrific, regardless of the country of origin, but for some it matters that Lilya is of post-Soviet origin. To one reviewer of the film, it is precisely this that 'makes [her] plight infinitely sadder' than if she were from a wealthy country (Holden, 2003, E20). The post-Soviet female Russian, because of her fallen status, adds to the inhuman abuse of the child Lilya, which in turn supports a view that the new Swedish law is justified and in line with the dominating political sentiment. The law is still without parallel in the European Union, which is divided on the question of prostitution, locked between viewing female prostitution as 'sexworkers' or abused women. Sweden and the Nordic countries see themselves at the forefront of combating prostitution, connecting strongly to feminist ideas that uneven society produces not only men empowered with the ability to buy sexual favours, but also women who are forced to sell themselves. ${ }^{16}$

The Europe divided over prostitution can also be detected in the music score of the film. As an additional source for the film, Moodysson recalls listening to Bach’s Mass in Bminor one sleepless night and envisioned celebrating a religious mass of our time (Gentele 2002, 60). Moodysson's goal was to unearth the divine in our time, the divine that gives hope even in the most hellish of situations. Like Bach, the Lutheran composer writing music for the Catholic mass, Moodysson endeavoured to make a film that would awaken Europe into following Sweden's lead in dealing with the exploitation of women. The reference to Bach ties in well nationally with the use of the German heavy-metal

of the perpetrator the age of consent is 18 , the legal age of adulthood. In this sense, Lilya is still a child and the men who use her paedophiles.

${ }^{15}$ The interview conducted by Danny Leigh is also available on The Guardian Website (Leigh 2002).

${ }^{16}$ In countries with social security, prostitution is normally connected to drug addiction, domestic abuse and (at the margins) illegal immigration. 
group Rammstein’s song Mein Hertz Brennt [My Heart Burns] in the film’s opening, which shows a bruised and disorientated Lilya running through the desolate streets of an industrial provincial town. Obviously the opening song is a reference to how Moodysson views the subject of the film, human trafficking. Of the opening scene, Emma Wilson comments: 'Moodysson creates a staccato effect through jump-cut, with relentless repetition as the camera is closer, then more distant, then closer again. [S]uch cutting, and the blistering music of the soundtrack generate sensations of friction, of collision’ (2005, 335-36). ${ }^{17}$ The two music points of Rammstein and Bach are references pointing to a Germanic affinity, which imparts the story of Russian Lilya to a Nordic European setting, as opposed to a purportedly southern European laissez-faire attitude towards prostitution and human trafficking.

Thus, despite the fact that critics were divided in their perception of Lilya 4-ever, the appearance of the film in a Swedish context is linked to the introduction of the law banning the purchase of sexual favours, which is again reflected in the divided European opinion on how to tackle sex work. The film makes use of the Russian Other in commenting on a transnational European reality, where the post-Socialist subject is seen as the victim of a poverty that strips the subject of agency. In this sense, SwedishRussian Lilya diverges from the Soviet Russian portrait of the same journey.

\section{Russian-Swedish Tanya}

Tanya, the central character in Interdevochka, is a high-class sex-worker, who lives her life in two separate worlds. During the day, she works as a nurse and shares a modest flat with her mother, but at night she_-of her own choice- turns to prostitution, selling sexual favours in glitzy foreign-currency bars and hotels. When one of her clients, the

\footnotetext{
${ }^{17}$ Contrary to Wilson, Tony Rayns finds the use of Rammstein's song inorganic: 'it is absurd to imagine that Lilya would ever relate to- or even listen to-a Rammstein track' $(2003,58)$. As a critic who writes mainly on Asian cinema, but occasionally ventures into other territories, Rayns is making a rather harsh judgment. Why should Rammstein be out of reach for people living in post-Soviet countries? Is it because the band sings in German or because it is 'Western'? Clearly, the level of foreign-language proficiency in the post-Soviet countries is greater than in Britain. Moreover, the Western music scene, Rammstein included, has built up sizeable markets in Eastern Europe and Russia. To Izvestia, the Russian daily, Moodysson explains that he encountered Rammstein while shooting Lilya 4-ever in Estonia: 'when we were filming in Estonia, I saw on a fence the word "Rammstein." I knew that this was a German group and decided to listen to it. I wanted to understand why this music attracts Estonian and Russian youngsters' (Kuvshinova 2003). Contrary to Rayns, I regard the arrangement of Rammstein and the rest of the music score, including the Russian girl-band Tatu, as working effectively to reflect the feelings of both the character and filmmaker.
} 
middle-aged and half-bald Swede, Edward, proposes to her, she believes she has struck fortune. Tanya desires to marry a foreigner in order to escape her Soviet life and reach the Western luxuries, which she can ill afford on salary as a nurse. Edward's marriage proposal becomes for Tanya the ticket out of the Soviet Union and into the dreamt of Western society.

The first part of the film concentrates on Tanya's efforts in leaving the Soviet Union, getting papers stamped, convincing her mother of the sincerity of the marriage and seeing to her mother's needs in her absence. In the second part of the film, Tanya lives in middle-class suburban luxury in Sweden, in an IKEA styled home and with her own cabriolet Volkswagen (this, of course, being the Soviet idea of Western luxury). The only problem is that housewife Tanya has nothing to do and she quickly grows tired of her dull materialist lifestyle and develops a nostalgic longing for her mother-and her Motherland, the Soviet Union. Following an affair with a Russian truck driver, Tanya decides to leave Sweden, but on the way to the airport she crashes her car and, we are left to assume, is killed.

Interdevochka [Intergirl] was made in 1989 by Petr Todorovsky, who was one of masters of the Soviet melodrama genre, ${ }^{18}$ but who, in the post-1991 era, has not managed to attain the success of his Soviet films and, in particular, Interdevochka. The film was a glasnost blockbuster, seen by 40 million Russians in its first year of release alone (Graffy 2000, 243). It won the popular vote contest in Soviet Screen, a leading Soviet film journal, the same year (Lawton 1992, 97). There are many factors contributing to the success of Interdevochka. Primarily, it was due to the 'different way of life'; the high-class prostitution which the film depicts should not be disregarded as an audience attraction (Bogomolov 1994, 22). The subject of prostitution in the Soviet Union would have been completely taboo only a few years earlier (Graffy 2000, 243). Nor should the critique of the Soviet system that the film implies be discounted. The film implies that Tanya's choice of her nightly profession is a direct result of a system that breeds moral prostitution (Lawton 2004, 61). Another key factor in the popularity

\footnotetext{
${ }^{18}$ Best exemplified by the film, Lyubimaya zhenshchina mekhanika Gavrilova [The Favourite Woman of the Mechanic Gavrilov] (1981), starring the popular Soviet actress Lyudmila Gurchenko. Of later achievements, Todorovsky remade Abram Room's famous triangle drama Bed and Sofa (1927) with Retro vtroem [Ménage à trios] (1998).
} 
of the film was the shooting of the second part on location in Sweden, as opposed to the 'phoney West' of the Soviet Baltic republics (Lawton 1992, 259-60 n85). ${ }^{19}$ This credibility of filming on location adds to the film's public impact, insofar as Interdevochka offered a glance into the forbidden West, which for many Soviet citizens was considered utterly alien territory.

Opinions on Interdevochka are divided. David Gillespie, for example, observes that, 'the message [of Interdevochka] is clear: good girls stay in Russia with their families and should not think above their (domesticated) station' (2003, 98). Anna Lawton, emphasising the critique of the Soviet system, adds that 'it would be misleading to read the film in moralistic terms — bad girls go astray [and] meet with retribution' (Lawton 1992, 213). Interdevochka is a simple melodrama, in that the film confirms a nationalistic ideal: the female Russian should stay at home. The film plays out the dictum of 'it is better to stay at home despite our troubled times.' For example, Tanya's cultural capital as a nurse is cinematically constructed as positive and valuable, in order for the viewers to question her desire to leave. We, as viewers, are expected to question the usefulness of sitting in suburban Sweden doing nothing, when one's true skills could be put to better use where they are needed at home in the Soviet Union.

In Russia, the narrative of women failing to successfully migrate is not uncommon. Karin Sarsenov, a Swedish Russianist, analysing literary narratives about Russian females abroad, describes two of the most popular Rodina [Motherland] narratives as a circular trajectory and a one-way journey (Sarsenov 2006, 6). In the circular narrative, the protagonists travel abroad only to return and confirm that the Motherland is far superior to the foreign country visited. This narrative can be seen in popular comedies, such as Okno v Parizh [Window to Paris] (Mamin, 1994), or action films, such as Brat 2 [Brother 2] (Balabanov, 2000). ${ }^{20}$ That said, the circular narrative, which is common to

\footnotetext{
${ }^{19}$ Tellingly, Moodysson opts for Estonia on the Baltic as the shooting location; the Baltic becomes a surrogate for 'Russia' in a Nordic filmmaking context.

${ }^{20}$ In Brat 2 the popular character of Danila Bagrov, played by the late Sergei Bodrov Jr., ventures into Chicago where he saves Dasha, a Russian prostitute who had immigrated to the US during Glasnost, from her black pimp and repatriates her by taking her home to Russia. Saved by Danila, Dasha realises that it was wrong to emigrate and upon leaving the US at the airport, she forfeits her right to enter the country again. On board the plane back to Russia the soundtrack plays a popular Nautilus song, 'Goodbye America,' that symbolises the end of post-Soviet Russia's love affair with the USA in the early 1990s (also called the Honeymoon period, 1991-1994). Brat 2 by Aleksei Balabanov illustrates well the circular narrative, where home is preferred to abroad.
} 
Russian cinema, frequently gets subverted when viewed from abroad. Here, the return journey can reveal the opposite of finding Russia superior. For example, in émigré narratives the protagonist often returns 'home' to find that leaving the country was the right choice. ${ }^{21}$ In these émigré narratives, the return home is not filled with salvation.

The one-way journey centres on negative narratives regarding Rodina [the Motherland], in that they are concerned with the themes of treachery and exile. While both films considered are one-way journeys - both female protagonists die in Sweden-in her afterlife Lilya returns home. This makes the narrative of Lilya 4-ever a confirmation of the Russian myth of 'Rodina' [the Motherland] as superior to abroad. Viewed in this light, Interdevochka is a classic melodrama in which the fallen woman realises her mistake, but is tragically killed before returning home. In the Russian-Swedish narrative of Tanya, the desire to travel abroad is equal to dishonour and the film thus projects a patriotic and nationalistic outlook.

\section{Narrative Structure and Mother Abandonment}

Despite the different contexts of the two films, the structure of the two narratives is constructed in accordance with the same formula. Both films have an extended spatial contextualisation of the Soviet era, or the post-Soviet-era in the case of Lilya 4-ever, where the conditions of the female protagonists are explained. Roughly at the same point in the narratives (two-thirds through) the films cut to the Soviet/Russian abroad, ${ }^{22}$ where the two females are not given the chance to be accepted as individuals. Whereas Swedish-Russian Lilya’s exclusion from Swedish society is more obvious, RussianSwedish Tanya is equally subject to rejection. For example, at a garden-party in Sweden, she endures an attempted rape from a colleague of her husband, who repeatedly refers to her as the Russian whore. In short, both protagonists are contained within their bodily profession — prostitution. Both women fight this forced identity, but in vain, and subsequently face no other recourse but suicide. What, then, are the reasons for this

\footnotetext{
${ }^{21}$ Such a realisation occurs in the French production Est-Ouest [East-West] (1999) by Régis Wargnier. Here French-Russian émigrés are lured back to Soviet Russia in the 1940s by the promise of new lives, only to be arrested and sent to labour camps by the Stalinist regime. Leonid Gorovets's Israeli film Kafe $V$ 'Lemon [Coffee with Lemon] (1994) also fits this category. Here the protagonist returns to Russia after failed migration to Israel, only to be accidentally shot during the siege of the White House in Moscow in 1994. Both Gorovets's and Wargnier's films highlight the viewpoint of the émigré, which inverts the dominant Russian Motherland narrative.

${ }^{22}$ While in Lilya 4-ever, the protagonist is depicted flying to Sweden, no diegetic travel is indicated in Interdevochka.
} 
similarity in the construction of the Russian transnational narrative? First of all, it is important that we keep the target audiences in mind. Both narratives aim to comprehend the desires to leave the 'home' country, and each film does this with different incentives. In the Russian-Swedish narrative of Tanya, the motivation is to present the protagonist's wish for migration as morally dubious, risky, illegal, and against the dominant political ideology. While trying to obtain permission to leave the Soviet Union, Russian-Swedish Tanya encounters many obstacles on the road to procuring her stamps, reminders to Soviet Russian audiences that the emigration process is filled with sacrifice, public rejection and personal loss. This is evident in the fate of Tanya's mother, who gets into trouble in her work as a teacher, directly because of Tanya's emigration application. Tanya's marriage and subsequent application to migrate raises questions about the mother's position as a role model for young students.

Whereas the Soviet contextualisation with regard to the Russian-Swedish Tanya narrative is intended to make viewers doubt the value of migration, in the SwedishRussian Lilya narrative, the post-Soviet environment functions to inform SwedishEuropean viewers about the circumstances of transnational migration. In short, it emphasises why people in post-Socialist countries contemplate migrating to Sweden. Similarly to the plot line for Russian-Swedish Tanya, Lilya's mother also has a crucial place in this regard, because her abandonment of Lilya triggers her downfall and eventually leads to Lilya accepting the offer of going to Sweden. The case of Lilya's mother and her migration to the USA without her daughter could be questioned in terms of plausibility, because official emigration involves following a strict set of bureaucratic rules to do with dependants. ${ }^{23}$ However, those rules are moot in this case; Lilya 4-ever does not specifically address Russian viewers. Instead, the mother's emigration functions to direct audience empathy to Lilya, rendering Lilya's entry into prostitution as dictated by destitution rather than free will. Therefore, according to Wilson, the abandonment of Lilya creates the most emotive scene of the film, wherein the spectator's identification with the female protagonist reaches a high point: 'Lilya is the child the viewer has been [or] a child the viewer has left behind, a reminder of parental responsibility and its visceral ties' (2005, 337). Wilson's analysis certainly makes sense in terms of the screened child and its audience reception, but the argument can be

\footnotetext{
${ }^{23}$ Russian-Swedish Tanya’s effort alone indicates that emigration is subject to vigilant control.
} 
further advanced. Moodysson evokes a parental relationship of exploiter and exploited, of the rich parenting — or lack of parenting — the poor. And those relationships resonate for the target audiences of Lilya 4-ever, firmly in place in the First World and, in particular, in the Nordic countries.

Moreover, the abandonment of Lilya infuses the mother with negative connotations, as she selfishly improves only her own situation, and hence the film refuels the negative narrative of transnational female migration. In her anthropological analysis of Moldovan mothers in a transnational migration circuit between Moldova and Turkey, Keough describes the representation of Lilya's mother and her choice to seek a better life as constructing 'one solution for desperate women like Lilya and her mother: Don't be a slave to passions for men or money; stay home, buck up, and take care of your responsibilities' (2006, 457 n11). Clearly, the bulk of the blame for Lilya's predicament, and her subsequent turn to sexwork, is placed upon the mother's desire to better her life. Had the mother not desired this, then Lilya would never have become a prostitute, travelled to Sweden, and later committed suicide. Viewers are led to conclude that transnational female migration gives impetus to a negative trajectory for the postSocialist subject, confirming that, despite the impoverished and un-nurturing motherland, post-Socialist mothers should avoid transnational endeavours. This ideology of Lilya 4-ever confirms the 'anxiety' narrative and contradicts economic policies that would help the development of the post-Socialist region. This would be the Swedish-Russian narrative’s message on transnational movement.

\section{Agency and Prostitution}

The leading protagonists in both films prostitute themselves prior to arriving in Sweden, but in positioning the two protagonists' act of allowing their bodies to be used for sexual favours against each other, the films reveal significant differences as to whether the two characters exercise any control over their respective actions. Obviously, Swedish-Russian Lilya lacks any control in her trajectory towards sexwork and her actions are forced upon her by others: her mother, her aunt, Andrei, her Polish-Swedish pimp Witek, and the 'customers' that use her. Lilya lacks command over earthly life and only gains control (agency) in her after-life. Due to Lilya’s lack of agency, Moodysson's film inclines towards a Neo-Realist vision of the lower classes being pushed around by the ruthless forces of capitalism (see Holden 2003). Indeed, if Italian 
Neo-Realism was often explicitly left wing in its solution to the mess of post-war Europe, this political purview is also evident in the public discourse on the film that Moodysson generated in newspaper interviews. Julian Graffy compares Lilya to the saintly prostitute Sonia in Dostoevsky's Crime and Punishment (1866) (2003, 22). If Dostoevsky's Sonia caused the murderous Rashkolnikov to crumble with guilt, then equally it is Moodysson's intention that audiences should crumble under the guilt of the ruthless exploitation that governs Lilya's trajectory. As he states in an interview, ‘everybody has a responsibility to take on the fact that these children's lives are a product of the society in which we live .... We all carry a tangible guilt for the hunger in the world' (Domellöf-Wik 2002, 50). The fact that Graffy makes this reference to Dostoevsky's character, Sonia, who derives salvation through her own suffering, reenforces the idea that Lilya 4-ever emerges from the mould of realism with a religious twang. 24

Neo-Realism reacted against the middle-class melodrama, which is the generic base of Russian-Swedish Tanya’s trajectory. Where Lilya is stripped of agency, Tanya is in full control of her actions in Soviet Russia, at least. Tanya's choice to become a prostitute is made deliberately in order to gain agency over her life, without which it would have been a version of Soviet middle-class 'poverty,' whereby white-collar workers had average incomes but no access to Western luxuries. Russian-Swedish Tanya's desire to better her situation is fulfilled by prostitution. Tanya can acquire Western luxuries by prostituting herself. The two characters' trajectory into prostitution resembles in this way the filmmakers' divergent opinions on female sexwork: the exploited child Lilya on the one hand, and the empowering sexworker in Tanya on the other. Yet, despite Tanya's agency, which empowers her over patriarchal political authorities, her subsequent migration and tragic death, framed by the generic conventions of the melodrama, mean that audiences are only expected to pity Tanya and her endeavours. Like Swedish-Russian Lilya, if Russian-Swedish Tanya had not migrated from the Soviet Union, but remained to question the rationality of the political ideology, she could have become a glasnost icon of feminist empowerment. As the films have it, then,

\footnotetext{
${ }^{24}$ Anna Lawton compares Tanya to another literary Russian character. She asserts that if the melodramatic genre had an effect on readers of 'Poor Lisa' two centuries ago, then it did the same to glasnost audiences viewing 'Poor Tanya' (1992, 213). The former reference is to the 'tearful tale' of Poor Liza (1792) by Nikolai Karamzin, in which the slick dandy cheats the simple flower girl of her innocence, upon which she commits suicide in a lake (Figes 2003, 59).
} 
the agency purportedly at work in the protagonists' choice of profession is depicted as failure; both Lilya and Tanya find their transnational progressions lead nowhere, and both films thus end with the suicide of the protagonists.

\section{Two Tragic Ends}

The endings of the two films reveal their ideological values. In Russian transnational narratives, the ending signifies whether the film has a positive return or a negative exile. This comparison is made possible by the fact that both protagonists die in an ultimately fashion at the end of the films and both characters end their lives at their own hands, by suicide. Only Lilya 4-ever contains a twist in its final solution, to which I shall return in a moment.

After attempting to leave her husband, Tanya is watching television, which reflects the emptiness of her Swedish life. The film then cuts to the Soviet context-the last of several jump-cuts that establish parallel narratives after Tanya's emigration-where a neighbour finds Tanya's mother dead on her kitchen floor. She has committed suicide upon finding out her daughter was a prostitute before leaving the country and after losing her teaching post on account of her daughter's emigration. Back in Sweden, Tanya senses that something has happened to her mother, rushes to the phone, and books a flight to Leningrad. Her husband Edward returns home with reconciliation flowers, but Tanya hides from him and leaves without saying goodbye. She takes her car and drives towards the airport. Tears stream from her eyes, enhanced by the heavy rain falling outside on the windshield. The music score that accompanies Tanya's final journey is the choral rendering of the song 'Along the Wild Steppes Beyond the Baikal,' which tells of a pre-revolutionary Russian vagrant who suffers for the truth. This is, of course, a direct reflection on the emotional condition of Tanya, who has realised her wrong doings and subsequently has to suffer for it. Tanya lets go of the steering wheel and the film ends.

Interdevochka is more ambiguous on account of its climax, and indeed some accord Tanya's final demise to a mere traffic accident (Lawton 1992, 212; Gillespie 2003, 98). The Russian review in Iskusstvo Kino [Art Cinema] is ironic in tone, but also points to Todorovsky's ambiguous end: 
Madame Larson is speeding on the night highway leading to the airport, the lights from the oncoming cars beat into her eyes ... and suddenly the headlights fill the screen ... The film stops, we have arrived. No, worse: Tanya is no more, she gets stopped forever in Sweden. And we are sitting in a humble rural theatre, far away from Moscow and Stockholm, and cry over her fate. It's a shame. Poor devil, she was a good girl—sincere, ours, Russian ... (Gul'tsenko 1990, 67)

If Todorovsky remains ambiguous in his film, then the novel on which the film is based is not. In it Tanya commits suicide. Thus, as Sarsenov asserts, while Tania is initially 'placed firmly with the traitors, falling prey to western consumerism,' in her tragic end 'she is elevated to a righteous "exile" when her love for the motherland drives her to suicide' (2006, 3). While I agree with Sarsenov that Tanya ends her life journey on the Swedish road to the airport, in my opinion Tanya's act is less a sacrifice than a last resort. Sensing that her mother has died, Tanya believes she has no one left in Russia to care for and hence no reason to return. A return seems as meaningless as staying abroad. Tanya has reached a dead-end; the only solution left appears to be to put an ultimate end to any journey. The film's end, then, is unambiguous. Interdevochka is a one-way journey in which the Russian female protagonist's venture into the foreign cannot be redeemed by her return to the homeland. Or, as Karin Sarsenov asserts, 'Tanya's allembracing Russian soul apparently could not fit into the petty, calculating, and materialistic environment, [but] her willingness to sacrifice herself redeems her from her former sins' (2006, 3). For Russian-Swedish Tanya, the return home is impossible because of her initial sin in wanting to migrate from Soviet Russia.

In the Swedish-Russian narrative of Lilya, the finale of the film returns to the beginning, where Lilya is running along the desolate streets of Malmö. As Lilya reaches the bridge, a vision of Volodia in angel wings joins her. ${ }^{25}$ Despite Volodia's discouragement, Lilya jumps off the bridge. As she lies in an ambulance, a male paramedic voice describes Lilya as he sees her, while Volodia's ghost appears in-between the shoulders of the paramedics. As the paramedics attempt to resuscitate Lilya, she opens her eyes. The film cuts to a scream from Lilya; she is back in her mother's apartment, again with Volodia in angel wings. 'You are for real', she tells him. As she runs down the stairs,

\footnotetext{
${ }^{25}$ Volodia has done so on previous occasions, for example, when Lilya in the capture of the apartment builds a hut from blankets over a coffee table, resembling the 'cocoons-cum-coffins' (Wilson 2005, 336). This echoes Lilya's and Volodia's effort to separate themselves from the outside world. Just as in the apartment scene, Volodia appears at Lilya's side with angel wings, vindicating Volodia's suicide upon Lilya's departure to Sweden.
} 
Lilya tears out an intravenous drip and upon reaching Andrei sitting in his car, she tells him, 'I'm not going. You don't pick vegetables in the winter. I'm no fool.' Back in the apartment, Lilya and Volodia play with Volodia's basketball refilled with air-its puncture symbolising Volodia's lost childhood-while the camera slows down and rests completely on Lilya with her arms up to reach the ball and looking directly into the camera. The film then cuts to the rooftop of the building block where Lilya and Volodia are playing with the ball; Lilya now also has a pair of angel wings.

Tanya in the Russian story is elevated from being a traitor to tragic exile, confirming her status as ‘a fallen woman' who has foolishly pursued her personal goals at the expense of failing her mother. But for Lilya, in the Swedish-Russian narrative, death is the only way out of the hellish inferno that has entangled her. Death for Lilya is the only relief where she returns home to 'Russia.' The Swedish-Russian narrative of Lilya performs the circular return plot that is denied to Russian-Swedish Tanya. Moreover, in Lilya 4-ever, the music score that follows the end scenes begins with Rammstein's song, but when Lilya appears on the bridge, Rammstein's music disappears into the background and stops completely when Lilya jumps. This is a pivotal point in the film. Once in 'the womb-like space' of the ambulance (Wilson 2005, 336), Lilya is narrated by the reality surrounding her (the paramedic's voice). This is the first time during the film that Moodysson leaves the perspective of his character, and it is here that we find a significant change in the music score. Rammstein is replaced by Vivaldi’s violins, which stay with Lilya as she returns to Russia to redeem her wrong decisions, that is, to say no to Andrei and refuse to travel to Sweden. The score's montage of Rammstein and Vivaldi, the Germanic bleeding heart versus the Italian light-romantic, ${ }^{26}$ signifies also the leap from realism to the meta-real. That this is a pivotal moment in the film is supported by Wilson's reading: 'The film cuts to Lilya in the ambulance, taking us beyond the point reached at its opening to Lilya's general circulatory arrest' $(2005,336)$. While for Wilson this 'circulatory arrest' is of no significance, in fact it is the point when Lilya is given a second chance to choose not to travel and is transformed into an angel at 'home.'

\footnotetext{
${ }^{26}$ In Swedish interviews, Moodysson alludes to a split in European attitudes towards prostitution when he reflected on the fact that Lilya 4-ever premiered at the Venice Film Festival in 2002. He is reported to have said, 'it is interesting that Lilya 4-ever is screened just there, in a country that has maybe the largest problem with young women from Eastern Europe. But it seems like the authorities are not really doing anything direct about it' (Domellöf-Wik 2002).
} 
It goes without saying that Moodysson's desire to make a grand finale for his 'religious mass of our time' has prompted this flight into the meta-real. ${ }^{27}$ Lilya's heaven is a wishfulfilment fantasy on three levels: for diegetic Lilya, for the compassionate viewer and for the filmmaker, Moodysson. With the ending, however, the narrative of Lilya clings on to the Russian circular 'Rodina' narrative and resembles the old Russian discourse of returning to the Motherland. It is hardly surprising that Interdevochka informs this motherland narrative, since it is a Russian melodrama. Because of this, Lilya 4-ever, in my opinion, reinstates the female Russian as Other, as a European Other, in a Eurocentric framework. The female Other is thus narrated as in need of rescue, but her rightful spatial location is always in the 'home' country. This reveals that the Nordic/European anxiety narrative of post-Socialist transnational labour undermining Western welfare systems has the same trajectory as the Russian return narrative, which is so loved by patriotic Russian cinema and literature. For both narratives the return home enables salvation. The comparison I have presented here thus confirms that the Swedish-Russian narrative denies the post-Soviet Russian a transnational space within the European-Nordic sphere, and reveals that post-Soviet Russia (re-)emerges as the border where Europe ends — or starts, if the Russian point of view is assumed. This continues to underline the Russian female identity abroad as Other in the European space, whether that identity is told by a Swede or a Soviet Russian.

\section{Conclusion:}

In the end, I rate Moodysson's film highly, and have no intention of belittling the importance of putting human trafficking on the political agenda, which Lilya 4-ever does to a previously unimaginable degree. However, I find it revealing that the story of Swedish-Russian Lilya has so much in common with the melodramatic story of Russian-Swedish Tanya, which is considered conservative and patriotic by most critics. There is no question about Moodysson's sincerity in seeking to make explicit the horrors of the system of human trafficking, but he does this by reiterating a conservative Russian 'return home’ narrative. Paradoxically, had he contemplated subverting this

\footnotetext{
${ }^{27}$ This flight into the meta-real is also seen in the ending of Lars von Trier's Breaking the Waves (1996), where the ringing of the bells in heaven signals the salvation of the leading female character, Bess, and the redemption of her earthly self-sacrificial torment. Swedish reviewers of Lilya 4-ever often link the two films (see Domellöf-Wik 2002 and Janson 2002). In my view, both Trier in Breaking the Waves and Moodysson in Lilya 4-ever owe their focus on female suffering to the Dostoevskian religious question: 'Can there be a God when there is so much suffering in the world?' While Dostoevsky mused over the question his entire life, the two young filmmakers answer with an emphatic Yes.
} 
narrative, Moodysson might have let Lilya live a happy and prosperous life in Sweden.

But that was not an option. As he says, 'I cannot lie. This is what society looks like'

(Domellöf-Wik 2002, 50).

\section{Acknowledgements}

I would like to thank Andrei Rogatchevski, Dina Iordanova and Emily Munro for their helpful suggestions and comments on earlier drafts. I would also like to thank the attendees of Diasporas, Migration and Identities, postgraduate conference (Leeds University, 2006), for their encouragement of the initial paper. Finally, I am grateful to Portal's anonymous reviewers for their keen critique, which helped vastly to improve this essay.

\section{Reference List}

Balabanov, A. (dir.) 2000, Brat 2 [Brother 2], STV Kinokompaniya.

Bergfelder, T. 2005, 'National, Transnational or Supranational Cinema?: Rethinking European Film Studies,' Media, Culture and Society, vol. 27, no. 3, 315-31.

Bodrov, S. (dir.) 2001, Bear's Kiss, Pandora Filmproduction.

Bodrov Jr., S. (dir.) 2001, Syostry [Sisters], STV Kinokompaniya.

Bogomolov, Y. 1994, 'Cinema for Every Day,' in Russian Critics on the Cinema of Glasnost, eds. M. Brashinsky and A. Horton, Cambridge University Press, Cambridge, 18-23.

Butterworth, J. (dir.) 2001, Birthday Girl, FilmFour.

Chen, E. 2005, 'Igrushki—eshchë bol’shee zlo, chem kino,' Gazeta, 3 Feburary. [Online] Available: http://gzt.ru/culture/2005/02/03/071500.html.

Domellöf-Wik, M. 2002, 'Moodyssons inlägg i debatten,' Göteborgs Posten, 23 August.

Engvén, I. 2002, 'Inom verklighetens murar: Lilya 4-ever,' Filmrutan, no.4, Årgång 45.

Ezra, E. and Rowden, T., eds. 2006, Transnational Cinema: The Film Reader, Routledge, New York \& London.

Figes, O. 2002, Natasha's Dance: A Cultural History of Russia, Penguin, London.

Gentele, J. 2002, 'Mörkt ämne i Moodyssons nya film,' Svenska Dagbladet, 16 August.

Gillespie, D. 1999, 'New Versions of Old Classics,' in Russia on Reels, ed. B. Beumers, I.B.Tauris Publishers, London \& New York, 114-24.

Gillespie, D. 2003, Russian Cinema, Pearson Educational, Harlow.

Gorovets, L. (dir.) 1994, Kafe V'Limon [Coffee with Lemon], Gadi Kastel.

Graffy, J. 2000, 'Petr Todorovsky,' in The BFI Companion to Eastern European and Russian Cinema, eds. R. Taylor, N. Wood, J. Graffy and D. Iordanova, BFI Publishing, London.

Graffy, J. 2003, 'Trading Places,' Sight and Sound, vol. 13, no. 4, 20-22.

Gul'tsenko, V. 1990, 'Stokgolm slezam he verity,' Iskusstvo Kino, no. 1, 1990, 62-68.

Hedling, O. 2004, 'Om Lilja 4-ever-en svensk film,' in Från Eden till Damavdelning, eds. B. Jonsson, K. Nykvist and B. Sjoberg, Absalon, Lund, 323-34.

Hjerten, L. 2002, 'Lukas Moodysson: Filmen är becksvart - Han vill få publiken att förändra sina liv och tänka efter,' Aftonbladet, 16 August, 36.

Hjort, M. 2005, 'From Epiphanic Culture to Circulation,' in Transnational Cinema in a Global North: Nordic Cinema in Transition, eds. T. G. Elkington \& A. Nestingen, Wayne State University Press, Detroit, 191-218.

Holden, S. 2003, 'Hopes Disintegrate Into a Life of Degradation,' New York Times, 18 April, E20.

Janson, M. 2002, 'Mästerverk av Moodysson - Drama,' Svenska Dagbladet, 23 August, 72.

Jones, K. M. 2003, 'Lilya 4-ever: Lukas Moodysson, Sweden, 2002,' Film Comment, vol. 39, no. 2, March/April 2003, 73-74.

Keough, L. J. 2006, 'Globalizing "Postsocialism”: Mobile Mothers and Neoliberalism on the Margins of Europe,’ Anthropological Quarterly, vol. 79, no. 3, 431-61.

Kuvshinova, M. 2003, 'Nikogda ne govori “navsegda”,' Izvestia, 15 April. [Online] Available: http://www.izvestia.ru/culture/article32683/.

Lawton, A. 1992, Kinoglasnost: Soviet Cinema in Our Time, Cambridge University Press, Cambridge. Lawton, A. 2004, Imaging Russia 2000: Film and Facts, New Academia Publishing, Washington, DC. 
Leigh, D. 2002, 'Lukas Moodysson at the NFT,' The Guardian, 20 November. [Online] Available: http://film.guardian.co.uk/interview/interviewpages/0,,848248,00.html.

Lind, A. (dir.) 1910, Den hvide slavehandel [The White-Slave Trade], Fotorama.

Mamin, Y. (dir.) 1994, Okno v Parizh [Window to Paris], Fontaine SARL.

Moodysson, L. (dir.) 1998, Fucking Åmål [Show Me Love], Memfis Film.

Moodysson, L. (dir.) 2000, Tillsammans [Together], Memfis Film.

Moodysson, L. (dir.) 2002, Lilya 4-ever, Memfis Film.

Moodysson, L. (dir.) 2004, Et hål i mitt hjerte [A Hole in My Heart], Memfis Film.

Moodysson, L. (dir.) 2006, Container, Memfis Film.

Neumann, I. B. 1996, Russia and the Idea of Europe: A Study in Identity and International relations, Routledge, London.

Neumann, I. B. 1999, Uses of the Other: 'The East' in European Identity Formation, Manchester University Press, Manchester.

Pawlikowski, P. (dir.) 2000, Last Resort, BBC.

Rayns, T. 2003, 'Lilya 4-ever,' Sight and Sound, vol. 13, no. 5, 56-58.

Room, A. (dir.) 1927, Tretya meshchamskaya [Bed and Sofa], Sovkino.

Todorovsky, P. (dir.) 1981, Lyubimaya zhenshchina mekhanika Gavrilova [The Favourite Woman of the Mechanic Gavrilov], Mosfilm.

Todorovsky, P. (dir.) 1989, Interdevochka [Intergirl], Mosfilm.

Todorovsky, P. (dir.) 1998, Retro vtroem [Ménage à trios], Myrabel Film.

Tuckers, G.L. (dir.) 1913, Traffic in Souls, Independent Moving Pictures.

Wargnier, R. (dir.) 1999, Est-Ouest [East-West], UGC YM.

Trier, L von (dir.) 1996, Breaking the Waves, Zentropa Film.

Sarsenov, K. 2006, 'Kann den Reisen Sünde sein? Drei russische Romane über mobile Frauen,' Osteuropa, vol. 6, 123-38. [English version available online: www.eurozine.com].

Shohat E. 1992, 'Notes on the "Postcolonial,”' Social Text, no. 31/32, 99-113.

Wilson, E. 2005, 'Children, Emotion and Viewing in Contemporary European Film,' Screen, vol. 46, no. 3, Autumn, 329-40.

Wolff, L. 1994, Inventing Eastern Europe: The Map of Civilization on the Mind of the Enlightenment, California University Press, Stanford. 